\title{
Studi Kasus Motivasi Belajar Siswa sebagai Anak Buruh Migran di SMP Negeri 1 Bandung Tulungagung
}

\author{
Reiska Yunita Dewi*, IM. Hambali, Yuliati Hotifah \\ Universitas Negeri Malang, Jl. Semarang No. 5 Malang, Jawa Timur, Indonesia \\ *Penulis korespondensi, Surel: dewireiska@gmail.com
}

Paper received: 3-5-2021; revised: 24-5-2021; accepted: 28-5-2021

\begin{abstract}
This study aims to increase knowledge about the influence of parents 'presence when children learn and learning motivation of migrant workers' children at SMP Negeri 1 Bandung, Tulungagung. The type of research used is a case study, through interviews with snowball sampling techniques, which are likened to getting information continuously and will only stop when the data is saturated. In addition, the interview technique used by researchers is in-depth interviews. The research steps carried out were preceded by observation, the first observation conducted by the researcher examined the data of students who have parents as migrant workers. Researchers also conducted interviews with counseling teachers regarding the learning behavior of migrant workers' children in class and what problems usually bother the students of migrant workers in learning. Observations that the two researchers conducted were by way of frank observation entering the classroom and observing the learning and learning process in which there were students of migrant workers' children. The results of the observations show that the learning behavior of students of migrant workers' children is different from those of students who are not children of migrant workers. Therefore, the researcher decided to do a research to find out what motivates the students of migrant workers to learn. Data collection, the researcher chose 4 students who according to the researcher were included in the category as data sources. Researchers conducted interviews with 4 children of migrant workers with in-depth interviews. Furthermore, data analysis is carried out by means of data reduction, data display, and conclusion drawing / verification. Meanwhile, to test the validity of the data using the credibility test (internal validity).
\end{abstract}

Keywords: learning motivation; learning behavior; parent attendance; children of migrant workers; junior high school students

\begin{abstract}
Abstrak
Penelitian ini bertujuan untuk menambah pengetahuan tentang pengaruh kehadiran orang tua saat anak belajar dan motivasi belajar siswa anak buruh migran di SMP Negeri 1 Bandung, Tulungagung. Jenis penelitian yang digunakan adalah studi kasus (case study), melalui wawancara dengan teknik sampling snowball yang diibaratkan mendapatkan informasi secara terus menerus dan baru akan berhenti saat data telah jenuh. Selain itu teknik wawancara yang digunakan peneliti adalah wawancara secara mendalam (in depth interview). Langkah penelitian yang dilakukan diawali dengan observasi, observasi yang pertama dilakukan peneliti memeriksa data siswa yang memiliki orang tua sebagai buruh migran. Peneliti juga melakukan wawancara kepada guru BK mengenai bagaimana perilaku belajar siswa anak buruh migran saat di kelas dan masalah apa saja yang biasa mengganggu siswa anak buruh migran dalam belajar. Observasi yang kedua peneliti lakukan dengan cara observasi terus terang ikut masuk kedalam kelas dan mengamati proses belajar dan pembelajaran yang didalamnya terdapat siswa anak buruh migran. Hasil dari observasi menunjukan perilaku belajar siswa anak buruh migran yang berbeda dengan siswa yang bukan anak buruh migran. Oleh karena itu peneliti memutuskan melakukan penelitian untuk mengetahui apa yang dapat menjadi motivasi belajar siswa anak buruh migran. Pengumpulan data, peneliti memilih 4 siswa yang menurut peneliti masuk dalam kategori sebagai sumber data. Peneliti melakukan wawancara kepada 4 siswa anak buruh migran dengan wawancara mendalam. Selanjutnya analisis data dilakukan dengan cara data reduction, data display, dan conclusion drawing/verification. Sedangkan untuk uji keabsahan data menggunakan Uji credibility (validitas internal).
\end{abstract}

Kata kunci: motivasi belajar; perilaku belajar; kehadiran orang tua; anak buruh migran; siswa SMP 


\section{Pendahuluan}

Motivasi belajar adalah proses yang memberi semangat belajar, arah, dan kegigihan perilaku. Artinya, perilaku yang termotivasi adalah perilaku yang penuh energi, terarah dan bertahan lama (Suprijono, 2009). Menurut Winkel (2007), motivasi belajar adalah keseluruhan daya penggerak di dalam diri siswa yang menimbulkan kegiatan serta memberi arah pada kegiatan belajar.

Menurut Dimyati dan Mudjiono (2002) "Motivasi seseorang dapat berupa motivasi intrinsik dan motivasi ekstrinsik". Motivasi intrinsik berarti motivasi yang ada pada diri seseorang tersebut dan motivasi ekstrinsik berarti berasal dari luar diri seseorang tersebut. Motivasi belajar yang dimiliki siswa pada setiap kegiatan pembelajaran sangat berperan untuk meningkatkan prestasi belajarnya. Siswa akan berhasil dalam belajar apabila dalam dirinya ada keinginan untuk belajar. Siswa yang memiliki keinginan belajar atau motivasi belajar akan berpengaruh pada kegiatan belajar di sekolah sehingga siswa lebih aktif dalam proses belajar di kelas.

Berdasarkan dari beberapa pengertian di atas dapat diambil kesimpulan bahwa motivasi belajar adalah suatu dorongan atau daya penggerak dari dalam diri individu yang memberikan arah dan semangat pada kegiatan belajar, sehingga dapat mencapai tujuan yang dikehendaki. Jadi peran motivasi bagi siswa dalam belajar sangat penting. Dengan adanya motivasi akan meningkatkan, memperkuat dan mengarahkan proses belajarnya, sehingga akan diperoleh keefektifan dalam belajar.

Keluarga merupakan tempat awal proses sosialisasi bagi anak, tempat memperoleh pemenuhan kebutuhan sarana dan prasarana dan kasih sayang dalam bentuk perhatian orangtua. Hal ini sejalan dengan yang dikemukakan oleh Sumadi Suryabrata (2004) bahwa "perhatian orangtua dengan penuh kasih sayang terhadap pendidikan anaknya, akan menumbuhkan aktivitas anak sebagai suatu potensi yang sangat berharga untuk menghadapi masa depan". Lalu dalam keluarga tersebut orang tua menerapkan pola asuh yang bagi mereka sesuai dan dibutuhkan anaknya dengan tujuan anaknya dapat menyelesaikan tugas dan kewajiban serta mendapatkan haknya sebagai anak dalam keluarga.

Guna meningkatkan motivasi belajar, orang tua memiliki peran penting dalam hal tersebut, sebab orang tua adalah orang terdekat dan paling berpengaruh dalam memotivasi anak. Orang tua pada umumnya memotivasi belajar anak dengan cara menemani saat belajar, memantau nilai, memberi semangat saat nilai anak turun dan memberikan dorongan untuk tetap belajar. Sedangkan orang tua sebagai buruh migran memiliki hambatan dalam memberi motivasi belajar pada anak. Karena, orang tua sibuk bekerja hingga tidak bisa menemani anak belajar apalagi jika orang tua bekerja di luar negeri yang memiliki perbedaan waktu hingga membuat anak kurang diperhatikan dalam belajar.

\section{Metode}

Jenis penelitian yang digunakan adalah studi kasus (case study). Studi kasus merupakan serangkaian kegiatan penyelidikan untuk mendeskripsikan dan menganalisis secara intensif dan terperinci suatu gejala atau unit sosial tertentu, seperti individu, kelompok, komunitas, atau lembaga (Sugiyono, 2018). Pengumpulan data dilakukan pada natural setting (kondisi yang alamiah), sumber data primer, dan teknik pengumpulan data lebih banyak pada observasi berperan serta (participant observation), wawancara mendalam (in depth interview), dan dokumentasi. (Sugiyono, 2018). Peneliti akan menggunakan observasi dan wawancara untuk 
teknik pengumpulan data pada penelitian. Observasi yang akan dilakukan adalah observasi tak berstruktur. Selain itu teknik wawancara yang digunakan peneliti adalah wawancara secara mendalam (in depth interview).

Dalam penelitian kualitatif, yang menjadi instrumen atau alat penelitian adalah peneliti itu sendiri. Oleh karena itu peneliti sebagai instrumen juga harus memahami seberapa jauh peneliti kualitatif siap melakukan penelitian yang selanjutnya terjun ke lapangan. Peneliti kualitatif sebagai human instrument, berfungsi menetapkan fokus penelitian, memilih informan sebagai sumber data, melakukan pengumpulan data, menilai kualitas data, analisis data, menafsirkan data dan membuat kesimpulan atas temuannya (Sugiyono, 2018).

Sumber data dalam penelitian ini adalah informasi langsung dari subjek maupun dari informan dan dokumentasi yang digunakan sebagai data tambahan. Menurut Lofland dan Lofland (dalam Moleong, 2012), sumber data utama dalam penelitian kualitatif ialah kata-kata dan tindakan, selebihnya adalah data tambahan seperti dokumen dan lain-lain. Subjek dari penelitian ini adalah siswa SMP kelas VIII-D.

\section{Hasil dan Pembahasan}

Pada hasil penelitian menunjukkan, perilaku belajar yang berbeda-beda. Bruner (dalam Budiningsih, 2012) mengemukakan bahwa belajar adalah menjelaskan proses belajar. Para siswa memiliki gaya tersendiri saat melakukan kegiatan belajar yang nyaman dengan mereka, mulai pemilihan jadwal belajar, cara belajar, hingga dengan siapa mereka belajar. Mereka akan cenderung memilih sesuai dengan kepribadian dan situasi mereka, agar tidak tumpang tindih dengan kegiatan harian mereka. Hal inilah yang membuat perilaku belajar setiap siswa berbeda-beda.

Perilaku belajar siswa anak buruh migran tentunya berbeda, setiap siswa memiliki kecenderungan lebih menonjol pada salah satu keterkaitan diatas. Faktor yang memengaruhi pun beragam, dari faktor lingkungan dan keluarga serta diri siswa tersebut. Faktor lingkungan seperti lingkaran pertemanan dan masyarakat sekitar dapat memengaruhi bagaimana siswa tersebut dalam perilaku belajar. Siswa bisa saja memiliki teman yang saling mendukung kegiatan belajar dan siswa bisa saja memiliki teman yang membuatnya asing dalam kegiatan belajar. Masyarakat sekitar juga dapat memengaruhi perilaku belajar siswa, dari bagaimana dukungan moral mereka saat melihat seorang anak buruh migran mengenyam pendidikan. Sedangkan faktor keluarga merupakan lingkup paling dekat dengan siswa, apalagi dukungan orangtua sangat memengaruhi bagaimana siswa tersebut berproses. Namun karena salah satu bahkan kedua orang tuanya harus bekerja jauh dari siswa, dukungan tersebut tidak maksimal dirasakan siswa anak buruh migran tersebut.

Kehadiran orangtua merupakan faktor penting karena orangtua adalah anggota terdekat dengan siswa yang mana memiliki peran penting sebagai pendidik utama serta pertama bagi anak-anak mereka. Orangtua adalah tempat pertama seorang anak memulai dan memiliki pendidikan dasar sebelum menempuh pendidikan di lingkup sekolah. Sehingga orang tua memegang tanggung jawab atas pendidikan anak dari anak masih kecil sampai anak dewasa.

Temuan penelitian tentang motivasi belajar siswa anak buruh migran, sesuatu yang membuatnya terdorong untuk semangat belajar karena merasa butuh untuk belajar. Siswa anak buruh migran, menempatkan keluarga sebagai faktor utama penyemat dalam belajar. Rasa ingin membanggakan dan meraih cita-cita untuk keluarga, terutama orang tua yang sudah 
rela mencari nafkah jauh dari keluarga agar keluarga hidup berkecukupan. Temuan tersebut sesuai dengan teori motivasi yang dipaparkan, yaitu teori hirarki kebutuhan yang dikemukakan oleh Maslow (1943), motivasi erat hubungannya dengan teori kebutuhan, yang mana manusia pada hakekatnya adalah memenuhi kebutuhannya. Namun selain teori kebutuhan tersebut, faktor intrinsik dan ekstrinsik juga memengaruhi seseorang memiliki motivasi untuk belajar. Motivasi intrinsik berarti motivasi yang ada pada diri seseorang tersebut dan motivasi ekstrinsik berarti berasal dari luar diri seseorang tersebut, menurut Dimyati dan Mudjiono (2002).

Faktor intrinsik dan ekstrinsik siswa anak buruh migran yang dimaksudkan adalah siswa anak buruh migran menanamkan pada dirinya bahwa belajar adalah kewajiban yang bila dilakukan dan dapat menghasilkan ilmu serta mendapatkan nilai yang bagus dapat membanggakan orang tua serta dapat membantu siswa meraih cita-citanya. Siswa anak buruh migran ingin membuktikan bahwa mereka yang hidup jauh dari perhatian orangtua, bukanlah anak yang tidak paham masa depan dan tidak memiliki cita-cita. Karena pada dasarnya siswa anak buruh migran dan siswa bukan anak buruh migran adalah sama, hanya keadaan yang membuatnya berbeda.

\section{Simpulan}

Berdasarkan hasil penelitian dapat dipaparkan simpulan yang diambil dari studi kasus motivasi belajar siswa sebagai anak buruh migran di SMP Negeri 1 Bandung. (1) Para siswa anak buruh migran memiliki perilaku belajar yang bervariasi, siswa anak buruh migran juga harus mahir dalam membagi waktu antara belajar dan melakukan aktivitas rumah, karena sebagian dari mereka menggantikan peran anggota keluarga di rumah. (2) Kehadiran orangtua saat anak belajar memiliki dampak bahkan penerimaan yang berbeda-beda. Namun meskipun penerimaan yang berbeda tetap saja semua anak menyebutkan kehadiran orangtua saat menemani belajar lebih membuat semangat dan termotivasi untuk belajar mengingat para orangtua harus tinggal jauh mencari nafkah demi sekolahnya juga. Motivasi belajar siswa anak buruh migran, sesuatu yang membuatnya terdorong untuk semangat belajar karena merasa butuh untuk belajar. Siswa anak buruh migran, menempatkan keluarga sebagai faktor utama penyemat dalam belajar.

\section{Daftar Rujukan}

Budiningsih. A. C. (2012). Belajar dan Pembelajaran.

Dimyati \& Mudjiono. (2002). Belajar dan Pembelajaran. Jakarta: PT. Raja Grafindo Persada

Maslow. A.H. 1943. A Theory of Human Motivation. Psychological Review. 50 (4), 370.

Moleong. L. J. (2012). Metodologi Penelitian Kualitatif. Bandung: PT. Remaja Rosdakarya.

Sugiyono. (2018). Metode Penelitian Pendidikan. Bandung: Alfabeta

Suprijono. (2009). Cooperative Learning Teori \& Aplikasi Paikem. Yogyakarta

Suryabrata, S. (2004). Psikologi Pendidikan. Yogyakarta: Andi Offset.

Winkel. (2007). Psikologi Pengajaran. Yogyakarta: PT. Gramedia. 